\title{
Die etiek van HM Kuitert na aanleiding van sy boek Suicide - wat is er tegen? Selfdoding in moreel perspectief
}

\author{
RM Naudé
}

\begin{abstract}
The ethics of HM Kuitert according to his book entitled, Suicide - wat is er tegen? Selfdoding in moreel perspektief

According to several publications Kuitert is criticised as a humanist. This paper tests his view on suicide to this accusation. It is found that Kuitert accepts teleology and solidarity as norms for his ethics and uses it as a method for his arguments against suicide. His goal is to offer an ethic which is acceptable for the Christian and the non-Christian. This results in outonomy with less emphasis on the theological argument against suicide. The result of this study is that the ethics of Kuitert cannot be described as mere humanism. Outonomy is judged as a form of theonomy.
\end{abstract}

Die, my dear Doctor? - that's the last thing I shall do (Palmerston)!

\section{INLEIDEND}

HM Kuitert is in 1924 in Nederland gebore. Na sy skoolopleiding het hy in die teologie gestudeer aan die Vrije Universiteit van Amsterdam in Nederland. Vanaf 1950 was hy predikant in Scharendijke en daarna studentepredikant in Amsterdam. In 1962 het hy aan die Vrije Universiteit gepromoveer onder prof GC Berkouwer. Sy proefskrif het gehandel oor: 'De mensvormigheid Gods. Een dogmatisch-hermeneutische studie over de anthropomorfismen van de Heilige Schrift'. Vanaf 1965 is hy aan die Fakulteit Teologie aan die Vrije Universiteit verbonde. In 1967 het hy prof JH van den Berg as professor in etiek opgevolg. Sedertdien het die etiek van Kuitert aktueel geword. Die rede hiervoor is dat Kuitert ' $n$ aantal publikasies laat verskyn het oor aktuele onderwerpe waarin hy die tradisionele beskouings van die teologie bevraagteken. Daarom word daar die afgelope tyd hewige kritiek op die denke 
van Kuitert gelewer. Verskeie etici spreek die oortuiging uit dat Kuitert humanisties is in sy beredenering. Velema se kommentaar op die etiek van Kuitert is: 'In alle etiese oorweginge word die humanum hoog geskat. Sy visie op etiese probleme soos revolusie, abortus en die beëindiging van die lewe verraai dat hy nie vra na die getuienis van die Skrif nie (Velema 1971: 115, 162). Die rede hiervoor is dat Kuitert in kommunikasie wil bly met die samelewing en relevant wil wees vir die moderne mens. Om dit te bereik is sy etiek algemeen menslik en nie spesifiek Christelik nie (Velema 1983: 16). Douma meen dat Kuitert 'n wyse van Christen-wees propageer wat sy hart geheel en al aan die mens en sy wêreld verpand het, deurdat hy humaniteit tot norm verhef vir die moraal (Douma 1972: 40). In sy proefskrif kom De Bruyn (1978: 172) tot dié konklusie: 'In elke afsonderlike aspek van sy etiek staan die mens in die sentrum en nie God nie. En daarom het Kuitert onteenseglik die Skriftuurlike en Gereformeerde pad verlaat en die onskriftuurlike pad van die humanisme gekies.'

Die doel van hierdie studie is om aan die hand van ' $n$ resente werk van Kuitert te bepaal of die kritiek teen hom geregverdig is of nie. Dit vereis dat nie alleen die boek ter hand in ag geneem sal word nie, maar dat die etiek van Kuitert soos dit ook na vore kom uit sy ander werke, binne die groter geheel van die Christelike etiek geplaas sal word. Om hierdie rede is die uitgangspunte van die etiek van Kuitert van groot belang.

\section{UITGANGSPUNTE}

\subsection{Solidariteit}

Die term solidariteit word nie deur Kuitert self gebruik nie. Dit is egter beskrywend van sy uitgangspunt dat teologiese argumente beperkte invloed het. Die beroep op die besondere openbaring het alleen geldigheid vir gelowiges en dan ook slegs vir gelowiges van dieselfde tradisie (Kuitert 1983: 70). Daarom beweeg Kuitert op die vlak van die moraal wat nie uitsluitlik Christelike moraal is nie. Sy doel is om algemeen geldige argumente op te bou. Met hierdie uitgangspunt van Kuitert is die probleem van solidariteit en antitese aan die orde gestel. Die vraagstelling wat met hierdie probleem gepaardgaan, kan as volg gestel word: Moet die belydenis van die evangelie nie verband hou met solidariteit met hierdie wêreld nie?; Is antitese nie te negatief nie?; Klink solidariteit nie mensliker nie? Ons kan die begrip antitese 
verbind met die teologie van Kuyper. Hy het dié begrip vanuit die filosofie diensbaar gemaak vir sy teologie. Die agtergrond hiervan is die volgende oortuiging van Kuyper: 'Al wat des Heren is moet nu finaal afgescheiden worden van dat duivelse dat in de creatuur indrong, te weten van de zonde' (Velema 1978: 11). Hiermee is geloof en ongeloof, Christendom en heidendom soos vuur en water beskryf. Dit kan nie met mekaar vereenselwig word nie. Die antitese tussen geloof en ongeloof vorm só 'n uitgangspunt vir 'n lewens- en wêreldbeskouing wat gestalte kry in die lewe van mense. Hierdie gestalte word duidelik deur die rigting wat Kuyper op grond van die antitese ingeslaan het. $\mathrm{Hy}$ het begin met die organisatoriese antitese deur Christelike organisasies op die gebied van die politiek, onderwys en maatskappy apart van die wêreld te organiseer (Velema 1978: 16). Vanuit hierdie Christelike 'selle' moes die wêreld kennis neem van die Christelike waardes.

Solidariteit verteenwoordig ' $n$ ander benadering van die wêreld of die sekulêre. Solidariteit in relasie met antitese dui op die samehorigheid van gelowiges en ongelowiges. Die Nederlandse Hervormde Kerk het in 1955 solidariteit beskrywe as die gemeenskap met die wêreld. Die fundering wat hiervoor gegee is, is dat die wêreld die voorwerp is van die genade van God (Velema 1978: 17). Solidariteit lê nadruk op die eenheid van Christen en nie-Christen in hulle optrede. Die kern van die saak lê by die saamwees en saamdoen in die wêreld. Vir Kuitert beteken solidariteit dat alle mense een gemeenskaplike basis en normering het in die ervaring. Kuitert stel dat 'n mens nie 'n Christen hoef te wees om tussen goed en kwaad te onderskei nie. Hy verklaar die mens, in sy kennis van goed en kwaad, onafhanklik van die Christelike geloof en die Christelike tradisie (Velema 1983: 7). Die agtergrond hiervan is Kuitert se beskouing in verband met moraal. Moraal is aan verandering onderhewig. Moraal is nie die gebod van God nie. Sy gebod kan nie verander nie. Moraal is egter die gehoorsaamheidsgestalte van die gebod en dit verander wel. God se gebod laat die mens soek na 'n moraal met die beste utiliteit. Op hierdie vlak is daar geen onderskeid tussen Christelike moraal en die nie-Christelike moraal nie. Moraal as gewoonte (Kuitert 1970: 184) of as gedrag met die beste konsekwensies vir die hele gemeenskap (Kuitert 1975: 72) is nie uitsluitlik Christelik nie. Christene en nie-Christene kan strewe na die beste utiliteit vir die gemeenskap en die resultaat sal wees dat die Christelike moraal soos twee druppels water sal vergelyk met die algemene moraal (Kuitert 1970: 196). Die spesifiek Christelike lê dus nie in moraal as verskynsel nie, maar kan wel in die kwaliteit van die 
moraal na vore kom. 'n Voorbeeld hiervan is dat die Christelike moraal meer liefde sal kan betoon as die algemene moraal (Kuitert 1970: 193). Met betrekking tot die kwaliteit van die moraal is die Skrifberoep onontbeerlik. Vir die moraal as verskynsel is daar egter ook ander bronne as die Skrif. Kuitert sê: 'De Bijbel is er niet voor de moraal, maar voor het verhaal, en (ik) bedoel daarmee dat wij voor onze kennis van wat mag en wat niet mag niet op de Bijbel zijn aangewezen'. Dit sluit nie uit '. . . dat we bij de Bijbel in menig opzicht te rade kunnen gaan als het om het vinden van een goede moraal gaat' (Velema 1983: 7). Etici wat hierdie uitgangspunt van Kuitert kritiseer, lees slegs die feit dat hy die Skrif nie as absoluut beskou nie. Daarom maak De Bruyn (1978: 90) die opmerking dat Kuitert die indruk wek dat hy Skrifberoep in die etiek laag waardeer en dit nie werklik as noodsaaklik ag nie. Ook Velema maak die konklusie dat die godsdienstige vir Kuitert geen inhoudelike betekenis het vir die morele nie (Velema 1983: 7). Dit laat nie reg geskied aan die uitgangspunt van Kuitert nie. Ander etici soos Gustafson steun die siening van Kuitert wanneer hy stel dat die uniekheid van die Skrif nie beteken dat sy gesag met betrekking tot moraal absoluut is nie. Die Skrif is noodsaaklik, maar nie selfgenoegsaam nie en daarom sê hy: 'An authority can be unique without being exclusive' (Birch \& Rasmussen 1976: 150). Kuitert ontken nie Skrifgesag nie. Hy erken wel die algemeenheid van moraal. Vanuit hierdie hoek wil Kuitert ' $n$ groot gevaar vermy wat hy bespeur het in die tradisionele argumentasie van teoloë, naamlik dat 'n morele keuse gemaak word en die Skrifberoep slegs dien om die reeds ingenome standpunt van gesag te voorsien (Kuitert 1983: 122-125). Kuitert stel dit duidelik dat hy 'n Christen is en dat die Christelike antwoord op lewensvrae vir hom onontbeerlik is. Hierin wil hy egter nie rigied wees deur antwoorde van nie-Christene te verag nie. Hy trag om sy oortuigings op só 'n wyse te stel, dat hy nie teen ander gelowe diskrimineer nie. Sy bedoeling hiermee is om só oor die Christelike geloof te skryf, dat dit aantreklik en aanvaarbaar vir elkeen is. Die Christelike antwoord moet homself aanbeveel te midde van ander antwoorde (Kuitert 1981: 80).

\subsection{Teleologie}

Teleologie as 'n verdere uitgangspunt van die etiek van Kuitert kan eers reg beoordeel word as die ontwikkeling in betekenis van dié begrip in aanmerking geneem word. Teleologie was aanvanklik nie antroposentries bedink nie. Aristoteles het teleologie gesien as 'n skema wat 
kausaliteit sistematiseer (Blumenberg 1962). Hiervolgens is die beskouing veral deur Kant gehuldig dat die werklikheid dinamies is. Dit word dus deur gedurige beweging gekenmerk. Hierdie beweging is meganies-noodwendig volgens universeel-geldende natuurwette. Die mees fundamentele en belangrikste van die natuurwette is die wet van oorsaaklikheid wat impliseer dat elke werking 'n genoegsame oorsaak moet hê en as die oorsaak bestaan, moet die bepaalde werking intree (Dreyer 1979: 64). Teleologie kan aan die hand hiervan beskryf word as die natuurproses wat op 'n doelwit afstuur. As sodanig is teleologie gesien as die teendeel van die teodisee-probleem. Dit het nie gehandel oor die vraagstuk van die prima causa nie maar wel oor die causa finalis. Teleologie is daarom gesien as die wêreldproses wat noodwendig afstuur op 'n gelukkige einde (Thielicke 1973: 253).

Die term teleologie is gaandeweg ook antroposentries benut. Teleologie is gebruik as ' $n$ term waarmee 'n teorie van etiese normering bedoel word. Dit het binne die filosofie bekend gestaan as gevolgsetiek. Die klem is geplaas op die resultaat van ' $n$ handeling. Iets is goed omdat dit goeie resultate oplewer. Die norm vir die beoordeling word dus by die gevolg van 'n handeling gevind. Goedheid is egter verskillend geïnterpreteer en daarom het verskillende sedelerige sisteme ontstaan soos hedonisme, eudaemonisme en utilitarisme. Respektiewelik is genot, geluk en nut as die summum bonum beskou (Dreyer 1979: 26-37).

CD Broad het egter met betrekking tot die antroposentriese gebruik van die term teleologie ' $n$ baie belangrike verandering gebring. Hy het teleologie in noue verband gebruik met deontologie as twee teorieë van etiese normering (Schüller et al 1974: 117). Hiermee is die term teleologie diensbaar gemaak as ' $n$ norm wat ten nouste verbind word aan die hermeneutiek van die etiek. Deontologie kan beskryf word as 'n fundamentalistiese Skrifgebruik. Wanneer die Skrif met betrekking tot etiese sake uitsluitlik deontologies gebruik word, word die Bybelse eis absoluut toegepas. Uitsprake van die Skrif word beskou as uitsonderinglose geldige gebooie en verbooie. Die uitsluitlik deontologiese Skrifhantering of ook genoem die absolute verpligte norm is nie houdbaar nie. Die volgende voorbeelde dui dit aan: As iemand 'n nier skenk vir sy seun, word dit gewoonlik geag as 'n onbaatsugtige prysenswaardige daad. As uitsluitlik deontologies hierna gekyk word, word dit beoordeel as selfverminking. ' $n$ Tweede voorbeeld: die verbod op leuentaal word dikwels deontologies beskou as 'n actus intrinsecus mali en daarom as absoluut verbode. Die moontlikheid dat die leuen 
wel geoorloof sou wees binne 'n situasie waar die lewe van mense op die spel is, word totaal uitgesluit.

Teleologie wil ook let op die gevolge wat' $n$ daad het. Dit wil nie dade uitsluitlik beoordeel volgens die gevolge wat dit het nie. So 'n beoordeling sou maklik kon eindig by die filosofiese gevolgsetiek. Teleologie wil in dialoog wees met deontologie en die situasie sodat die bedoeling van die Skrif tot sy reg sal kom in die lewe van mense. Kuitert verstaan deontologie as dié standpunt in die etiek waardeur 'n bepaalde handeling in homself as verplig of verbode voorgestel word. lemand doen iets nie om een of ander rede nie maar omdat dit nie mag nie. So sal iemand nie ' $n$ leuen vertel nie omdat dit nie mag nie en nie omdat dit ellende veroorsaak nie. Kuitert beskou teleologie as ' $n$ handeling wat om een of ander rede verplig of verbied word. Die redes wat gegee kan word, is deurslaggewend vir die beoordeling of ' $n$ handeling aanvaarbaar of onaanvaarbaar is. Kuitert is ' $n$ voorstander van teleologie. Daarom aanvaar hy nie die standpunt dat selfdoding onder geen omstandighede geoorloof is nie. Hy vra wel na die redes waarom dit as ongeoorloof of geoorloof beskou kan word (Kuitert 1983: 121-122). Met hierdie uitgangspunt is dit al duidelik dat Kuitert nie in sy etiek wetties te werk sal gaan nie, maar dat hy sal oorweeg en voor- en nadele teen mekaar sal opweeg om op hierdie wyse tot 'n resultaat te kom. Met betrekking tot selfdoding wat as 'n oorkoepelende term gebruik word, sou dit onmoontlik wees om dié saak anders te benader.

\section{SELFDODING}

\subsection{Terminologie}

Kuitert vermy die term 'selfmoord' omdat dit alreeds ' $n$ waarde-oordeel bevat. Hy verkies die term selfdoding omdat dit ' $n$ neutrale benadering tot hierdie vraagstuk verteenwoordig. Kuitert definieer selfdoding as volg: '. . . dit gaan om 'n dood wat die betrokke persoon aan homself doen as gevolg van uiteenlopende redes (Kuitert 1983: 17). Vanuit hierdie definisie is dit duidelik dat enige daad waardeur ' $n$ persoon aan die einde van sy lewe kom sonder die toedoen van iemand anders, deur Kuitert beskou word as selfdoding. Selfdoding word dus gebruik as 'n meer omvattender begrip as selfmoord. Ons kan selfmoord omskryf as die bewustelike en doelgerigte neem van 'n eie lewe. Selfdoding omvat selfmoord sowel as ' $n$ heldedaad soos dié van Wolraad Woltemade. Dit is ' $n$ aspek wat belangrik is vir die verstaan van Kuitert se redenasie. 
Die gebruik van die term 'selfdoding' laat egter nie reg geskied aan die onderskeid wat gemaak kan word tussen selfdoding en selfmoord nie. Selfdoding kan wel bruikbaar wees naas selfmoord om ' $n$ onderskeid te tref tussen twee handelinge waarvan die een onaanvaarbaar is omdat dit die doelgerigte neem van lewe is (selfmoord) en die ander aanvaarbaar is omdat meer as net die eie lewe op die spel is soos die lewe van ander mense (selfdoding). Alhoewel ons verskil ten opsigte van die gebruik van die term 'selfdoding' word dit so gehandhaaf ter wille van die korrekte weergawe van Kuitert se denke.

\subsection{Die klassieke - 'nee'}

In navolging van Bayet is Kuitert oortuig dat die afwysing van selfdoding wat in die Christelike tradisie voorkom nie vanuit die Christelike tradisie self voorkom nie. Bayet stel: '. . . dit was nee in die kerk maar nie van die kerk' (Kuitert 1983: 44). Kuitert trag om dié stelling te bewys. Thomas van Aquino (1225-1274) se argumente kan beskou word as die samevatting van die klassieke 'nee'. Hy het drie redes aangevoer waarom selfdoding absoluut ongeoorloof is:

- Dit is ' $n$ handeling wat in stryd is met die natuurlike neiging tot selfliefde en selfbehoud sowel as met die bonatuurlike liefde wat 'n Christen aan homself verskuldig is.

- Dit is ' $n$ daad van onreg teen die gemeenskap.

- Dit is sonde teen God omdat ons sy eiendom is en die reg op lewe en dood Hom toekom (Kuitert 1983: 46).

Wat die eerste argument betref, konstrueer Thomas twee weë van verpligting tot selfliefde en as keersy die verwerping van selfdoding as menslike moontlikheid. Die eerste weg is dié van die natuurlike selfliefde. Sy gedagte is dat die menslike natuur met die neiging tot selfliefde toegerus is. Daarom kies mens vir die lewe en teen die dood. Die mens het ook die natuurlike neiging om die goeie te doen en die kwade te vermy. Dit beteken dat die mens dit wat vir hom goed is, tot stand bring en dit wat nadelig is, vermy. Daarom is dit moreel ' $n$ goeie handeling om jouself lief te hê en die lewe te kies. Dit is egter moreel verkeerd om jouself te dood. Die vooronderstelling van hierdie redenasie is dat die lewe goed is en die dood sleg is. Die mens kan alleen hierdie vooronderstelling hê via die rede van die mens. Omdat die rede weet wat goed is vir 'n mens, weet die rede ook waarna die mens moet 
strewe. Kuitert meen dat hierdie beredenering van Thomas hom verbind met die klassieke Griekse etiek (Kuitert 1983: 46-50).

Wat die tweede argument betref, steun Thomas volledig op Aristoteles. Aristoteles het geredeneer dat die samelewing benadeel word deur selfdoding in dié sin dat dit die belange van die samelewing skaad. Thomas sien die mens as deel van die samelewing en daarom het die samelewing ' $n$ reg op die lewe van die burger en nie die burger self nie. Selfdoding word hiermee beskryf as ' $n$ aantasting van die reg wat die samelewing op die enkeling het (Kuitert 1983: 51). Thomas se derde argument (teologiese argument) is dat selfdoding teen God gerig is. Die mens is onderwerp aan die seggenskap van God. Wie homself dood, begaan dieselfde misstap as iemand wat moord pleeg. Alleen God het die reg om oor lewe en dood te beslis. Wie dié beslissing in eie hande neem, skend die regte van God. Kuitert meen dat hierdie redenasie van Thomas op die denke van Plato gegrond is. Plato het geleer dat die mens homself nie mag bevry uit die gevangenskap van die liggaamlike bestaan nie. Die mens mag sy pos (kerker) nie verlaat nie. Die mens moet wag op 'n weldoener. Plato grond sy oortuigings in die feit dat die mens nie aan homself behoort nie, maar dat God die eienaar is. Ons mag daarom nie eiemagtig optree deur ons eie lewe self te neem nie. Ons moet wag totdat Hy ons roep (Kuitert 1983: 52).

Kuitert trek in sy beredenering nie alleen 'n parallel tussen Thomas en die filosofie nie, maar hy beweer ook dat die teologie tans steeds dieselfde filosofiese denke in verband met selfdoding akkommodeer. So beskryf Geesink selfdoding as 'n misdaad wat die gemoed met afsku vervul. Die drie argumente van Thomas word in dieselfde volgorde gebruik. Ander etici gebruik sommige van dié argumente. Brillenburg Wurth beskryf selfdoding as selfmisleiding en daarom is dit nooit geoorloof nie. Dit is ook 'n bewys van ongeloof omdat die lewe 'n geskenk is wat eerbiedig moet word. Bonhoeffer veroordeel nie alle selfdoding nie. As iemand bereid is om homself op te offer vir iemand anders, is dit geoorloofde vryheid. As selfdoding selfvernietiging is, word 'n oordeel voltrek wat slegs in die hand van God lê. Barth beoordeel selfdoding as ' $n$ skending van die gebod van God. Dit is sonde en daarom praat Barth van 'eindeutig selbstmord'. Die rede hiervoor is dat ons eiendom van God is. Hy maak die genade van God van toepassing op alle mense en daarom beskou hy selfdoding nie as ' $n$ moontlikheid vir ongelowiges nie. Sфe gebruik die teologiese argument om selfdoding as immoreel te beskryf. Dit geld egter nie vir ongelowiges nie (Kuitert 1983: 59-64). Kuitert maak die gevolgtrekking dat die 
hedendaagse 'nee' weinig nuwe elemente bevat in vergelyking met die klassieke 'nee'. Die bekende argumente word herhaal sonder dat dit opnuut deurdink word. Die enigste verskuiwing wat plaasgevind het, is die klem op die teologiese argument, ten koste van die plig tot selfliefde en verpligting teenoor die samelewing. Kuitert vind dit betreurenswaardig omdat dit 'n leemte laat in die diskussie oor selfdoding. Die teologiese argument is te ingewikkeld om as enigste argument teen selfdoding te dien. Die beredenering wat strek vanaf Plato tot Barth dat die mens aan God behoort, laat vrae na vore kom wat moeilik te beantwoord is. Die vraag wat gevra kan word is: Waarom word selfdoding teengestaan, maar die doodmaak van ander word onder bepaalde voorwaardes goedgekeur? As gevolg van die problematiek wat die teologiese argument skep, meen Kuitert dat die ander twee argumente met groter vrug bespreek kan word (Kuitert 1983: $65-66)$.

Vir Kuitert is die rede vir dié beklemtoning van die teologiese argument dat die tradisionele argumentasie teenoor die siening van die Stoa gestel is. Die Stoa het geleer dat om 'n goeie lewe te hê, die mens goed moet leef. Dié lewensleer loop uit op 'n streng deugdeleer as die weg na geluk. Gepaardgaande met die deugdeleer word ook die siening gehuldig dat om ' $n$ goeie lewe te hê, die mens vry moet wees van die wêreld. Om vry te wees, is egter slegs die voorreg van die wyse. Omdat aardse dinge soos besit en lewe gelukkig kan maak, maar ook skade kan doen, is die wyse vry om dit te benut of daarvan afstand te doen. Alhoewel die Stoa selfdoding in die algemeen as immoreel beskou het, was dit wel geoorloof vir die wyse. Die rede hiervoor is dat die wyse mens weet wanneer sy tyd aangebreek het om die lewe te beëindig. Wanneer die lewe 'n las geword het as gevolg van siekte, byvoorbeeld, staan dit die wyse vry om homself te dood. Zeno ( $250 \mathrm{vC}$ ) het homself op die duim geslaan en dit as ' $n$ teken gesien dat God hom roep om die lewe te verlaat! In dié verband was die slagspreuk van die Stoa: '. . . die uitweg lê oop; sterwe is vry vir wie nie langer wil lewe nie; elke boom, elke afgrond roep jou toe: vryheid' (Kuitert 1983: 79-83). Die gedagte van Kuitert is duidelik: as gevolg van die oortuiging van die Stoa dat die mens vry is om homself te dood, het die teologie skerp gereageer en selfdoding teologies absoluut veroordeel. Kuitert wil daarom in sy beredenering trag om die balans in die beoordeling van selfdoding te herstel en terselfdertyd wil hy ook die ongelowige bereik deur klem te lê op die plig tot selfliefde en die plig teenoor die samelewing. 


\subsection{Lewensbeskouing}

Die teologie verdedig die stelling dat lewe 'n geskenk is van God die Skepper. Die lewe as geskenk is bedoel om as vreugdevol beleef te word. Daarom is dit ongeoorloof om vrywillig afstand te doen van die lewe. Wie dit doen, beledig die Skepper en staan skuldig voor God. Die mens het 'n plig tot lewe wat gegrond is op die feit dat God lewe gee. Daarom word gepraat van die heiligheid van die lewe en eerbied vir die lewe. Hiermee word nie bedoel dat geskapenheid eerbiedig moet word soos God eerbiedig moet word nie. Dit sou beteken dat skepping en verlossing saamval en dat die skepsel vereer word soos die Skepper. Met hierdie terme word eerder bedoel dat lewe 'n gawe van God is en in dié lig alleen groot waarde het. As sodanig ervaar die mens dat die lewe goed is. Christene sal die lewe aanbeveel op grond van die feit dat God dit gee. Kuitert meen egter dat alhoewel God die lewe gee en die mens dit as goed kan ervaar, dit nie beteken dat die mens nie selfbeskikking oor die lewe kan hê nie. Die bekende woorde van Job: '... die Here het gegee en die Here het geneem' beteken nie dat dit nie mense is wat gee en neem nie. Die feit dat God die Gewer is, het Christene in die verlede nie verhoed om die lewe van ander onder bepaalde omstandighede te neem nie. Daarom kom Kuitert tot dié gevolgtrekking: Die geloof dat God die Gewer van ons lewe is, dat die lewe heilig is en 'n geskenk is, kan nie beteken dat onsself nie oor lewe en dood beskik nie. Dit is nie beskikking wat veroordeel word nie, maar wel willekeurige beskikking! (Kuitert 1981: 81-84). Kuitert verwerp die gedagte dat die mens ' $n$ plig het om te leef. ' $n$ Plig tot lewe stel elkeen wat leef onder die verpligting om verder te leef. Alhoewel die meeste mense vir die lewe kies, beteken dit nie dat die enkeling die lewe nie anders mag waardeer nie. Omdat die mens outonoom is, kan goeie redes aangevoer word vir selfdoding (Kuitert 1983: 118-119). Hiermee weerspreek Kuitert nie sy standpunt dat willekeurige selfbeskikking ongeoorloof is nie. Die moontlikheid van selfdoding as outonomie moet gesien word in die lig van die leer van die handeling met die dubbele gevolg. Dié leer het betrekking op handelinge met gevolge wat voorsien kan word. In die praktyk kom dit voor dat 'n handeling 'n gevolg het wat voorsien kan word en wat gewil is. Daar kan ook gevolge wees wat voorsien kon word, maar wat nie gewil is nie. 'n Voorbeeld hiervan is die reeds genoemde geval van Wolraad Woltemade. Hy gee sy lewe om ander te red. Sy handeling bedoel nie om homself te dood nie, maar om sy medemens te red. Selfdoding kan in 
dié geval beskrywe word as 'n voorsiene, maar nie gewilde gevolg nie. Hiermee word ' $n$ handeling wat ongeoorloof is nie meteens geoorloof omdat dit goed bedoel is nie. Omdat hierdie handeling 'n gevolg het wat nie bedoel is nie, is dit moreel geregverdig. Woltemade het nie lewensveragtend opgetree nie, maar sy eie lewe ondergeskik gestel aan die lewens van ander. So ' $n$ daad word deur Kuitert as selfbeskikking beskryf. Die besluit om te red selfs ten koste van 'n eie lewe, is deur die persoon self geneem (Kuitert 1983: 145).

Dit is reeds opgemerk dat die taalgebruik van Kuitert misverstand kan skep. Die aanvaarding van selfdoding skep die indruk dat selfmoord in die algemeen goedgekeur word. Dit is nie die geval nie. Hy laat die moontlikheid oop dat iemand wat sy lewe prysgee ter wille van die lewe van ander, moreel geregverdig kan word. Ons noem hierdie standpunt van Kuitert die regverdiging van ' $n$ heldedaad. Dit is wel waar dat Kuitert in sy beredenering van goeie redes vir selfdoding ook ander moontlikhede in aanmerking neem as net die heldedaad. Hy stel nie net ' $n$ eie lewe teenoor ' $n$ ander se lewe nie, maar neem ook die moontlikheid in ag dat die kwaliteit van lewe wat ontbreek, 'n goeie rede kan wees vir selfdoding. Hy noem die voorbeeld van ' $n$ vader wat verneem het dat hy aan 'n ongeneeslike siekte ly. Omdat sy behandeling en versorging wat baie duur sou wees, sy gesin in 'n finansiële verknorsing sou dompel, besluit hy dat hy sy eie lewe sal neem. Die welsyn van sy gesin het meer waarde as sy eie lewe (Kuitert 1983: 147). Alhoewel Kuitert uitdruklik sê dat hy nie dié geval wil beoordeel nie, word die indruk gewek dat hy begrip het hiervoor en die rede as goeie rede kan ag (Kuitert 1983: 147). 'n Ander moontlikheid soos selfdoding as 'n ekspressiehandeling om daardeur politieke protes aan te teken, word deur Kuitert bevraagteken (Kuitert 1983: 149). Goeie redes vir selfdoding word nie sonder meer deur Kuitert as geoorloof beskou nie, alhoewel hy dié moontlikheid wil ooplaat ter wille van die respek vir die outonomie van die mens. Die klem wat Kuitert plaas op die outonomie kom sterk na vore wanneer hy die vraag stel of ' $n$ mens tussenbeide mag kom wanneer iemand 'n poging tot selfdoding aangewend het en nog lewe. Hy beskou dit as paternalisme wanneer iemand hom nie neerlê by dit wat ' $n$ ander kies of doen nie. Om tussenbeide te kom en die dood te voorkom by selfdoding, is om iemand se reg op outonomie te skend sonder toestemming van die betrokkene. Aan die ander kant erken Kuitert die prinsiep van weldoen wat 'n persoon dring om hulp te verleen al skend dit outonomie of al is dit paternalisties. Kuitert aanvaar uiteindelik 'n sintese: paternalistiese 
optrede is ' $n$ vorm van hulpverlening en kan as 'n morele verpligting beskou word. Ingryping in ' $n$ selfdoodpoging is geoorloof omdat selfdoding ' $n$ onherroeplike karakter het. Ander handelinge kan weer goedgemaak word, maar as met selfdoding fouteer word, is herstel onmoontlik. Tog laat Kuitert die moontlikheid oop dat ingryping in ' $n$ selfdoodpoging lyding kan veroorsaak, byvoorbeeld iemand wat van 'n gebou afspring se lewe word gered om as verlamde verder te lewe (Kuitert 1983: 169-179). Alhoewel Kuitert erken dat hulp by selfdoding allereers beteken om hulp te verleen met die oog op lewe, erken hy dat hulp ook kan beteken om te help om te sterf. Hierdie hulp geskied met farmaseutiese middels wat deur'n medikus toegedien moet word. Dit beskou Kuitert as euthanica (Kuitert 1983: 191). Sy beskouing oor hulpverlening maak dus voorsiening vir eutanasie.

\subsection{Kriteria}

Die kriteria wat Kuitert aanbied vir die beoordelingvan selfdoding sluit aan by die drie redes wat die klassieke 'nee' aanvoer teen selfdoding. Hy sien selfdoding as ' $n$ handeling waarmee ' $n$ mens ' $n$ ramp oor homself bring as die sterkste argument teen selfdoding. Verlies van lewe is 'n ramp omdat en vir sover lewe as iets goeds waardeer word (Kuitert 1983: 154). Hiermee word nie meer waarde aan lewe geheg as empiriese waarde nie. Die beëindiging van lewe is slegs 'n ramp as daardie lewe nog sin gehad het. Kuitert wil hiermee sê dat deur selfdoding as ' $n$ ramp oor jouself iemand homself beroof van die moontlikheid tot verdere ervaring en ontplooiing van die dinge wat die lewe die moeite werd maak (Kuitert 1983: 155). Die kriterium wat Kuitert gee, het dus twee kante: Lewe het empiriese waarde sowel as moontlike waarde wat ontplooi kan word. Albei aspekte laat hy funksioneer as argumentasie teen selfdoding. Aan die hand van die prinsiepe van weldoen, wil hy ook vra of 'n daad vir iemand tot voordeel strek of nie. Hiermee wil Kuitert sy benadering tot selfdoding baie sterk na vore bring. Hy wil nie soos die klassieke 'nee' van die selfdoder sê: Jy mag nie! Kuitert wil eerder sê: Jy doen 'n onreg aan jouself! Die tweede kriterium wat Kuitert handhaaf, is dat selfdoding gevolge het vir die gemeenskap. Die selfdoder moet vra na die gevolge van sy daad vir ander, omdat selfdoding selde ' $n$ indiwiduele handeling is. Die selfdoder het ' $n$ verantwoordelikheid teenoor ander mense. Daarom kan die verpligtinge teenoor ander 'n appél rig tot die lewe van die mens. Op grond hiervan is dit Kuitert se standpunt dat wanneer 
iemand homself dood, dit 'n versaking van verantwoordelikheid kan wees (Kuitert 1983: 161). Kuitert stel dit egter nie absoluut nie. Hy handhaaf ook die oortuiging dat 'n selfdoder geen skuld kan hê as niemand anders by sy daad betrokke is nie (Kuitert 1983: 157). Omdat hy selfdoding as ' $n$ daad sien wat selde indiwidueel van aard is, moet hierdie oortuiging as ' $n$ uitsondering beoordeel word. Kuitert wil nie soos die klassieke 'nee' aan die selfdoder sê: Jy het 'n onvoorwaardelike plig tot lewe nie! Hy wil eerder sê: Jy het 'n plig teenoor ander!

Die derde kriterium wat Kuitert stel, is 'n teologiese argument. Alhoewel hy dit as uitgangspunt gestel het dat hy só oor selfdoding wil skryf dat dit aanvaarbaar kan wees ook vir die nie-Christen, bied hy tog 'n paar opmerkings wat teologies van aard is. Hy vra die vraag of die Christelike geloof die sinvraag vir die selfdoder oplos. Die vraag na die sin van die lewe kom eers ter sprake as die ewewig in die lewe versteur word en daar onsekerheid kom. Die sin van die lewe kan daarom iets beteken as dit die ervaring van sinloosheid in bedwang kan hou. Alleen die geloof kan dit bereik omdat dit getuig dat sinloosheid, trane, onreg en geweld nie die laaste woord spreek nie. Geloof hou selfdoding op 'n afstand (Kuitert 1983: 164). Hiermee wil Kuitert nie soos die klassieke 'nee' aan die selfdoder sê: Jy moet lewe want God is Skepper nie! Hy wil eerder sê: Dit is goed om te lewe want God vind jou die moeite werd!

\section{OPMERKINGS}

Thielicke (1980: 89) het 'n gepaste opmerking gemaak: Hy het gesê dat as die ja van God tot die mens wat in die geloof gehoor en gehoorsaam word geen lewende elemente van ons bewussyn meer vorm nie dan kom ons tereg op die hellende vlak wat die mens voer van diviniteit via geëmansipeerde humaniteit na bestialiteit. Na aanleiding hiervan kan ons opmerk dat die besinning rondom selfmoord nooit sy verankering in die teologiese argument mag verloor nie. As gevolg van die vertrekpunt van Kuitert om algemeen aanvaarde argumente daar te stel, kom die teologiese argumente nie sterk na vore nie. Dit moet as 'n leemte beskou word. Dít laat die opening vir die aanvaarding van eutanasie as sterwenshulp aan die selfmoordenaar. Op hierdie punt wil ons radikaal met Kuitert verskil. Daarom is dit noodsaaklik dat die algemene norme wat Kuitert bied, van teologiese inhoude voorsien moet word. Sy etiek bied die ruimte daarvoor. Dit blyk veral uit die feit dat die etiek van 
Kuitert beskryf kan word as 'n etiek van medemenslikheid. Die etiek van medemenslikheid leer in verband met selfmoord dat die beslissing daarteen uitgelok word deur die onloënbare aanwesigheid van die ander met sy onbetwyfelbare appél. Die etiek van medemenslikheid vorm op dié wyse die matriks van alle normatiwiteit vir die mens (De Graaf 1971: 49). Dit word dikwels as suiwer humanisme verstaan, maar in werklikheid het dit dieselfde doelwit as wat Kuitert wil bereik, naamlik om normatiwiteit te skenk aan die lewe van mense wat aan alle norme twyfel. Die etiek van medemenslikheid bedoel dus nie om Chistelike norme te verdring nie, maar kan benut word vir die aanvaarding van Christelike norme.

Ons kan hiervoor aanknoop by die twee hoofargumente van Kuitert ten opsigte van selfmoord, naamlik selfliefde en die verantwoordelikheid teenoor die gemeenskap. Alhoewel dit algemene norme is, is dit ook spesifiek Christelik. Selfliefde asook naasteliefde wat die gemeenskap omsluit, is sowel 'n Bybelse gegewenheid as 'n opdrag (Matt 22: 34-40). Die mens is aan die een kant ' $n$ persoonlike wese wat sy eie welstand op die hart dra. Selfliefde beteken dat die mens met verantwoordelikheid teenoor God en teenoor homself sal optree. Aan die ander kant is die mens ook ' $n$ sosiale wese. Mense is op mekaar aangewese en kan ' $n$ appél tot mekaar rig. Die Bybelse eis van naasteliefde vra dat die mens nie net na sy eie belange sal omsien nie, maar dat hy ook en dikwels veral die belange van ander in ag sal neem. Albei hierdie aspekte is onontbeerlik by die proses van besluitneming en aksie. Die gedagte van Kuitert dat selfmoord selde ' $n$ individuele daad is, kan binne hierdie ruimte met vrug uitgebou word.

Die klem wat Kuitert lê op outonomie in die proses van besluitneming, word ten onregte as suiwer humanisme beskou. Outonomie kan slegs beskou word as die verwerping van 'n vreemde of bonatuurlike wil, wanneer teonomie as ' $n$ heteros nomos beskou word. Die kerngedagte hieragter is dat die mens alleen in die verhouding met God homself kan vind (Thielicke 1976: 238). Op hierdie wyse is teonomie en outonomie nie teenstellings nie. Die wil van God word ook die wil van die mens. Die wil van God is dan nie meer 'n Fremdkörper nie, maar dit word in die hart van die mens geskryf. Dié gedagte word uitgebou deur die ethics of being by wyse van die metaphor of character (Birch en Rasmussen 1975: 84-94). Die Skrif werk vormend in op die karakter van die mens. Dit beteken dat wanneer die mens beslissings moet maak, dit gedoen word as 'n karakter wat deur die Woord voorgesê is. Só ontstaan 'n wisselwerking tussen teonomie en outonomie. 
Dié enkele opmerkings wil die selfmoordenaar nie net konfronteer met homself en sy verantwoordelikheid teenoor die gemeenskap nie, dit wil hom ook konfronteer met God wat hom omvou met sy liefde en sy genade sodat hy die wil sal hê om voort te leef. Bonhoeffer verwoord dit op ' $n$ treffende wyse: In ure van vertwyfeling kan geen menslike of goddelike wet selfmoord voorkom nie. Hulp kan alleen kom deur genade en gebed. Nie die reg op lewe kan die versoeking oorwin nie, maar alleen die genade wat 'n mens toelaat om voort te leef onder die vergewing van God (Bonhoeffer 1955: 147).

\section{Literatuurverwysings}

BIRCH, B \& RASMUSSEN, L 1976. Bible and ethics in the Christian life. Minneapolis: Augsbury.

BONHOEFFER, D 1955. Ethics. Londen: SCM.

BLUMENBERG, H 1962. sv teleologie. RGG.

DE BRUYN, PJ 1978. Die plek van die mens in die etiek van HM Kuitert. Potchefstroom: Pro Rege.

DE GRAAF, J 1971. De ethiek van het immoralisme. Nijkerk: Callenbach NV.

DOUMA, J 1972. Voorbeeld of gebod? Enkele opmerkinge over het Schrift-beroep in de ethiek. Amsterdam: Bolland.

DREYER, PS 1979. Hoofstrominge van Sedeleer. Pretoria: HAUM.

KUITERT, HM 1970. Anders gezegd: Een verzameling theologische opstellen voor de welwillende lezer. Kampen: Kok.

KUITERT, HM 1975. Zonder geloof vaart niemand wel: Een plaatsbepaling van christendom en kerk. Vierde druk. Baarn: Ten Have.

KUITERT, HM 1981. Een gewenste dood: Euthanasie en zelfbeschikking als moreel en godsdienstig probleem. Baarn: Ten Have.

KUITERT, HM 1983. Suicide: wat is er tegen? Zelfdoding in moreel perspectief. Baarn: Ten Have.

SCHÜLLER, B, FURGER, F, JUROS, H, STYCZEN, T \& WILI, H 1974. Theologische Berichte, 4. Zürich: Benziger Verlag.

THIELICKE, H 1973. Theologische Ethik, II/1. Tübingen: Mohr.

THIELICKE, H 1976. Mensch Sein, Mensch werden. München: Piper.

THIELICKE, H 1980. Wie mag sterven? Ede: Zomer en Keuning.

VELEMA, WH 1971. Aangepaste theologie. Amsterdam: Buijten \& Schipperheijn.

VELEMA, WH 1978. Solidariteit en antithese. Kampen: Kok.

VELEMA, WH 1983. Hoe Christelijk is de Christelijke ethiek? Kampen: Kok. 